\title{
STRATEGI PENGENDALIAN EMOSI PADA ANAK USIA SEKOLAH DASAR UNTUK MENDUKUNG KECERDASANNYA
}

\author{
Mahmud \\ Universitas Islam Negeri Imam Bonjol Padang \\ mahmud@uinib.ac.id \\ Abdal Fajri \\ STIT Al-Azhar Diniyyah Jambi \\ fajri.afda191@gmail.com
}

\begin{abstract}
Every child is unique, which is the result of reactions to himself, developmental problems and environmental factors, as a result the child is often moody, temperamental, naughty and often interferes with the learning process. Therefore, this study focuses on the influence of emotional development on elementary school students using the literature study method through content analysis and content interpretation. The results of this study have proven that it takes some attention to school-age children such as health conditions, home atmosphere, relationships with family members, relationships with peers, protection of parents' aspirations, and how to educate and guide parents. Emotional regulation can be solved by controlling unpleasant or unpleasant emotions, which can be quickly balanced with pleasant emotions and the ability to develop emotions.
\end{abstract}

Keywords: Emotional Development, Learning, Intelligence

\begin{abstract}
ABSTRAK
Setiap anak memiliki keunikan yang merupakan akibat dari reaksi atas dirinya, permasalah perkembangan dan faktor lingkungan, akibatnya anak sering murung, tempramen, nakal dan sering sekali mengganggu proses pembelajarannya.Karenanya penelitian ini fokus pada pengaruh perkembangan emosi pada peserta didik tingkat sekolah dasar dengan metode studi pustaka melalui analisis isi (content analysis) dan interpretasi isi (content interpretation). Hasil penelitian ini berhasil mendapati bahwa diperlukan beberapa perhatian terhadap anak usia sekolah dasar diantaranya kondisi kesehatan, suasana rumah, hubungan dengan anggota keluarga, hubungan dengan teman sebaya, perlindungan aspirasi orang tua, serta cara mendidik dan bimbingan orang tua. Selanjutnya keseimbangan emosi juga dapat diperoleh melalui cara pengendalian lingkungan dengan tujuan agar emosi yang tidak atau kurang menyenangkan dapat cepat diimbangi dengan emosi yang menyenangkan, serta kemampuan mengembangkan toleransi terhadap emosi.
\end{abstract}

Kata kunci: Perkembangan emosi, pembelajaran, kecerdasan 


\section{PENDAHULUAN}

Setiap anak pada tahap perkembangan memiliki keunikan, bisa saja terkadang sangat mengejutkan. Bermunculan keunikan tersebut bisa saja menjadi kesulitan tersendiri oleh orang dewasa (orang tua) apabila tidak dimengerti dan terkesan sangat menyusahkan. Sehingga banyak bermunculan kesalahan sikap untuk merespon kejadian tersebut, hal yang sama juga diakui oleh guru disekolahnya. Salah satu aspek perkembangan yang sering merepotkan orang tua dan guru adalah perkembangan emosi. Anak sering bermasalah pada perkembangan emosinya pada umumnya di tandai dengankenakalan. Perilaku nakal umumnya merupakan bersifat normal pada anak-anak untuk tahap perkembanganya, tetapi ada kemungkinan lain yang menyerupai bagian dari goncangan jiwa atau gangguan emosi (Andi Widodo, 2018).

Ganguan emosi anak dalam banyak kajian merupakan salah satu pertanda perkembangan. Perkembangan dimaksud dapat turut serta memiliki peran menentukan keberhasilan individunya dalam kehidupan. Karena pada prinsipnya anak yang memiliki kemampuan intelektual/kognitif baik tetapi emosionalnya kurang memadai juga akan mengalami hambatan dalam kehidupannya . Sejumlah faktor yang mempengaruhi perkembangan emosi anak juga harus mendapat perhatian mendalam, baik dari dalam individu peserta didik, konflik-konflik dalam proses perkembangannya, maupun sebab-sebab yang bersumber dari lingkungan (Sari et al., 2020). Oleh sebab itu agar perkembangan emosi pada anak dapat diarahkan dengan baik, sebagai orang tua dan guru harus mengetahui tahap-tahap perkembangan emosi pada anak usia sekolah dasar.

Sarlito Wirawan Sarwono berpendapat bahwa emosi merupakan setiap keadaan pada diri seseorang yang disertai warna efektif baik pada tingkat lemah (dangkal) maupun dalam tingkat yang luas dan mendalam (Syamsu, 2014). Emosi dapat berupa perasaan amarah, ketakutan, kebahagiaan, cinta, rasa terkejut, jijik, dan rasa sedih. Semua gejala emosi seperti amarah, rasa takut, rasa gembira, senang, penuh harap, termasuk konflik, stres, cemas frustasi dan sebagainya mempengaruhi perubahan fisik seseorang (Rena, 2019). Emosi merupakan perasaan atau afeksi yang timbul ketika seseorang sedang berada dalam situasi atau keadaan atau suatu interaksi yang diangggap penting olehnya. Emosi diwakili oleh perilaku yang mewakili (mengekspresikan) kenyamanan atau 
ketidaknyamanan dari keadaan atau interaksi yang sedang dia alami (Darmiah, 2020). Selain itu, emosi juga dapat diartikan suatu kondisi intrapersonal, seperti perasaan, keadaan tertentu atau pola aktifitas motor (Setiani, 2013). Unit-unit emosi dapat dibedakan berdasarkan tingkatan kompleksitas yang terbentuk berupa perasaan menyenangkan atau tidak menyenangkan, komponen ekspresi wajah individu dan suatu keadaan sebagai penggerak tertentu. Jadi emosi adalah pengalaman afektif yang disertai penyesuaian dari dalam diri individu tentang keadaan mental dan fisik dan berwujud suatu tingkah laku yang tampak.

Adapun alasan penulis mengangkat kajian ini karena mengingat pentingnya keberadaan guru dan orangtua yang menjadi pemeran starategis sebagai subjek pembantu dan pembimbing emosional anak, keterlibatan secara intensifdan menjalankan fungsinya sebagai sumber rujukan pendidikan emosional perlu dilakukan, karenausia anak, sebagaimana disebutkan memiliki tingkat kerawanansesuai dengan tingkat perkembanganya. Maka dalam tulisan ini ingin menjawab dua pertanyaan yakni Bagaimanakah tingkatan perkembangan emosi pada ada anak usia sekolah dasar dan bagiamana implikasi perkembangan emosi anak usia sekolah dasar dalam pembelajaran.

\section{METODE PENELITIAN}

Penelitian denganmelalui riset kepustakaandengan serangkaian kegiatan yang berkaitan dengan pengendalian emosi dan kecerdasan anak.Pengumpulan data dilakukan studi pustaka, membaca dan mencatat, serta mengolah bahan penelitian.Informasi dari hasil studi pustaka itu dapat dilakukan pada tiga objekyang harus dihubungi, dilihat, diteliti, atau dikunjungi sehingga akan memberikan informasi yang dibutuhkan.Ketiga objek itu berupa tulisan (written texts), manusia (person), atau tempat (place) (Arikunto, 2016).Khusus pada penelitian ini penulis mengusahakan melakukan ganalisis dan mengetahui relevansi pengendalian emosi dengan tahapan kecerdasannya, serta mengetahui kekurangan jika tidak sedini mungkin dilakukannya pengendalian emosi pada anak usia sekolah dasar dilihat dari perspektif kecerdasan emosional.

Objek penelitian ini adalah buku yang membahas tentang kecedasan emosional dan perkembangan emosi pada anak usia sekolah dasar secara khusus yangdianalisis guna mencari relevansi dengan pengendalian emosi. Untuk kepentingan analisis data penelitian yang lebih rinci, maka penulis menggunakan beberapa metode memahami, mempelajari, dan menganalisa data-data yang 
telah dikumpulkan, dalam hal ini peneliti ini menggunakan metode analisis isi (content analysis), interpretasi isi (content interpretation) (Arafat, 2018).

\section{PEMBAHASAN}

\section{A. Ciri dan Klasifikasi Perkembangan}

\section{Emosi pada Anak}

Setiap anak memiliki beragam cara untuk mengungkapkan emosi pada dirinya, baik melalui sikap yang baik maupun kebalikan. Beberapa ciri-ciri berikut ini dapat menandakan macam-macam emosi pada anak.diantaranya adalah pertama, bersifat subjektif seperti pengamatan dan berfikir; kedua, bersifat fluktuatif; dan ketiga bersangkut paut dengan peristiwa pengenalan pancaindera. Ketiga kelompok itu dilihat berdasarkan sifatnya, sedangkan menurut Yudrik Jahja (Darmiah, 2020) bahwa emosi dapat dikelompokkan dengan pertama emosi sensoris, biasanya ditimbulkan oleh rangsangan dari luar terhadap tubuh: kedua emosi psikis, emosi yang mempunyai alasanalasan kejiwaan. Emosi psikis ditunjukkan dengan perasaan intelektual, perasaan sosial, perasaan susila, perasaan keindahan (estetika), dan perasaan ketuhanan.

Tahap perkembangan emosi pada anak dan remaja mengalami banyak tahapan, bisa saja terjadi banyak memiliki peran positif bagi perilakunya, maupun malah terjadi hal negatif pada diri anak.oleh karena itu beberapa fase emosi pada anak dapat merubah perilaku, diantaranya adalah pertama, memperkuat semangat, apabila ada orang merasa senang atau puas atas hasil yang dicapai. Kedua, melemahkan semangat, apabila timbul rasa kecewa karena kegagalan dan sebagai puncak dari keadaan ini adalah timbulnya rasa putus asa (frustasi). Ketiga, menghambat konsentrasi belajar, apabila sedang mengalami ketegangan emosi dan dapat juga menimbulkan sikap gugup dan gagap dalam berbicara. Keempat, terganggunya penyesuaian sosial, apabila terjadi rasa cemburu dan iri hati. Oleh karena itu, suasana emosional yang diterima dan dialami individu semasa kecilnya akan mempengaruhi sikapnya di kemudian hari, baik terhadap dirinya maupun orang lain. Canon bard merumuskan teori tentang pengaruh fisiologis terhadap emosi. Pernyataan tentang teori ini bahwa dapat menimbulkan situasi rangkaian proses syaraf anak. Suatu situasi yang saling mempengaruhi antara thalamus (pusat penghubung antara bagian bawah otak dengan susunan urat syaraf disatu pihak dan alat keseimbangan atau cerebellum dengan creblar cortex (bagian otak yang terletak didekat permukaan sebelah dalam dari tulang tengkorak, suatu bagian yang berhubungan 
dengan proses kerjanya pada jiwa taraf tinggi, seperti berfikir).

Menurut James dan Lange, bahwa emosi itu ditimbulkan dan dipengaruhi oleh perubahan jasmaniah individu. Misalnya, menangis itu karena sedih, tertawa itu karena gembira, lari itu karena takut, dan berkelahi itu karena marah. Lindsley mengemukakan apa yang disebut "Activition Theory" (teori pergerakkan). Pada teori ini disebabkan emosi oleh pekerjaan keras dari susunan syaraf manusia terutama pada otak. Contohnya bila seseorang sedang mengalami frustasi maka susunan syaraf bekerja sangat keras sehingga menimbulkan sekresi kelenjar-kelenjar tertentu dengan demikian dapat mempertinggi daya kerja otak, maka akan timbul emosi. John B. Waston menemukan ada tiga pola dasar emosi yaitu takut, marah, dan cinta (fear, anger, and love). Ketiganya menunjukkan respon tertentu dengan stimulus tertentu yang dilakukan, tetapi besar pula kemungkinan akan terjadi pula modifikasi (perubahan).

\section{B. Faktor-Faktor yang Mempengaruhi}

\section{Emosi Anak}

Berberapa faktor yang dapat memengaruhi perkembangan emosi anak adalah sebagai berikut. Pertama keadaan anak, keadaan individu pada anak, misalnya cacat tubuh ataupun kekurangan pada diri anak akan sangat mempengaruhi perkembangan emosional, bahkan akan berdampak lebih jauh pada kepribadian anak. Misalnya: rendah diri, mudah tersinggung, atau menarik diri dari lingkunganya. Kedua, faktor belajar, pengalaman belajar anak akan menentukan reaksi potensial mana yang mereka gunakan untuk marah. Pengalaman belajar yang menunjang perkembangan emosi antara lain: a) belajar dengan coba-coba. Anak yang belajar seperti ini akan belajar dengan mencoba-coba agar dapat mengekspresikan emosinya berupa perilaku yang akan memberi sedikit kepuasannya atau tidak memberi kepuasannya. b) Belajar dengan meniru, meniru adalah cara mengamati agar dapat dilakukan, dengan meniru dan mengamati apa yang membangkitkan emosi orang lain, anak biasanya beraksi dan berperilaku sebagaimana emosi dan metode yang sama dengan yang diamatinya. c) Belajar dengan mempersamakan diri, mempersamakan diri pada anak dilihat pada reaksi meniru emosional orang lain yang membuat dia tergugah, dan dilakukan dengan rangsangan yang sama sehingga telah membangkitkan emosi orang yang ditiru. Jadi anak biasanya akan meniru orang yang dikaguminya dan ikatan emosional yang kuat akan terpatri dalam dirinya. d) Belajar melalui 
pengondisian, belajar tipe ini melalui objek, dimana situasi yang pada awalnya gagal untuk memancing reaksi emosional akan namun kemudian berhasil karena dikombinasikan dengan asosiasi. Pengondisian biasanya terjadi dengan mudah dan cepat pada tahap awal kehidupan karena anak kurang menalar, mengenal betapa tidak rasionalnya reaksi mereka. e) Belajar dengan bimbingan dan pengawasan, anak diajarkan cara bereaksi yang dapat diterima jika suatu emosi terangsang. Dengan pelatihan, anakanak dirangsang untuk bereaksi terhadap rangsangan yang biasanya membangkitkan emosi yang menyenangkan dan dicegah agar tidak bereaksi secara emosional terhadap rangsangan yang membangkitkan emosi yang tidak menyenangkan (Novi Ade Suryani, 2019). Ketiga, konflik-konflik dalam proses perkembangan, setiap anak melalui berbagai konflik dalam menjalani fase-fase perkembangan yang pada umumnya dapat dilalui dengan sukses. Namun jika anak tidak dapat mengamati konflik-konflik tersebut, biasanya mengalami gangguan-gangguan emosi. Keempat, lingkungan keluarga, salah satu fungsi keluarga adalah sosialisasi nilai keluarga mengenai bagaimana anak bersikap dan berperilaku. Keluarga adalah lembaga yang pertama kali mengajarkan individu (melalui contoh yang diberikan orang tua) bagaimana individu mengeksplorasi emosinya. Keluarga merupakan lingkungan pertama dan utama bagi perkembangan anak.Keluarga sangat berfungsi dalam menanamkan dasar-dasar pengalaman emosi, karena disanalah pengalaman pertama didapatkan oleh anak.Keluarga merupakan lembaga pertumbuhan dan belajar awal (learning and growing) yang dapat mengantarkan anak menuju pertumbuhan dan belajar selanjutnya.

Gaya pengasuhan keluarga akan sangat berpengaruh terhadap perkembangan emosi anak. Apabila anak dikembangkan dalam lingkungan keluarga yang emosinya positif, maka perkembangan emosi anak akan menjadi positif. Akan tetapi, apabila kebiasaan orang tua dalam mengekspresikan emosinya negatif seperti, melampiaskan kemarahan dengan sikap agresif, mudah marah, kecewa dan pesimis dalam menghadapi masalah, maka perkembangan emosi anak akan menjadi negatif (Febiola \& Hazizah, 2019).

\section{Tingkat Perkembangan Emosi}

Tiga reaksi emosi yang paling kuat adalah rasa marah, kaku, dan takut, yang terjadi akibat dari peristiwa-peristiwa eksternal maupun proses tak langsung. Reaksi tersebut dapat tercermin dalam individu yang meningkatkan aktivitas 
kelenjar tertentu dan mengubah temperature tubuh. Reaksi umumnya berkurang sesuai proporsi kematangan individu. Hal ini disebabkan oleh pebedaan jenis reaksi emosi, misalnya dengan penyebab ketakutan pada diri seseorang anak mungkin disebabkan oleh jenis emosi yang berbeda sesuai dengan tingkat perkembangannya. Tingkat perkembangan emosi tidak terlepas dari tingkat kestabilan emosi seseorang yang meliputi: pertama, emosi stabil, pada seseorang yang mempunyai emosi stabil mempunyai kecenderungan percaya diri, cermat, kukuh. Mereka selaulu menjaga pikiran walaupun dalam keadaan kritis, sedangkan orang-orang di sekitarnya kehilangan kendali. Kedua, emosi stabil ratarata. Seseorang yang mempunyai derajat ratarata tingkat emosional mempunyai kecenderungan emosi keseimbangan yang baik, sabar, tak memihak, berkepala dingin. Mereka tidak kebal atas rasa khawatir dan terkadang menunjukkan emosi yang aneh, namun ini adalah pengecualian daripada kebiasaan. Ketiga, emosi labil, seseorang yang mempunyai emosi yang labil, tergesagesa, bernafsu, sentimental, mudah tergugah, khawatir dan bimbang.Mereka mungkin agaknya tertekan oleh kehidupan, hal ini membuat mereka mudah terkena hal-hal negatif dan positif, sekaligus kerap dipengaruhi oleh tragedi dan kesenangan serta tiak ada upaya untuk bereaksi mengatasi peristiwa-peristiwa tersebut dalam hidup.

\section{Perkembangan Emosi Pada Anak} Usia Sekolah Dasar

Perkembangan emosi pada anak melalui beberapa fase yaitu (Maria \& Amalia, 2018): Pertama. Pada bayi hingga 18 bulan, pada fase ini diperlukan 1) bayi butuh belajar dan mengetahui bahwa lingkungan di sekitarnya aman dan familier. Perlakuan yang diterima pada fase ini berperan dalam membentuk rasa percaya diri, cara pandangnya terhadap orang lain serta interaksi dengan orang lain. Contoh ibu yang memberikan ASI secara teratur memberikan rasa aman pada bayi. 2) Pada minggu ketiga atau keempat bayi mulai tersenyum jika ia merasa nyaman dan tenang. Minggu ke delapan ia mulai tersenyum jika melihat wajah dan suara orang di sekitarnya. 3) Pada bulan keempat sampai kedelapan bayi mulai belajar mengekspresikan emosi seperti gembira, terkejut, marah dan takut. Pada bulan ke-12 sampai 15, ketergantungan bayi pada orang yang merawatnya akan semakin besar. Ia akan gelisah jika ia dihampiri orang asing yang belum dikenalnya. Pada umur 18 bulan bayi mulai mengamati dan meniru reaksi emosi yang di tunjukan orangorang yang berada di sekitar dalam merespon 
kejadian tertentu. Kedua Fase kedua setelah fase pertama yakni usia 18 bulan sampai 3 tahun 1) Pada fase ini, anak mulai mencaricari aturan dan batasan yang berlaku di lingkungannya. Ia mulai melihat akibat perilaku dan perbuatannya yang akan banyak mempengaruhi perasaan dalam menyikapi posisinya di lingkungan. Fase ini anak belajar membedakan cara benar dan salah dalam mewujudkan keinginannya. 2) Pada anak usia dua tahun belum mampu menggunakan banyak kata untuk mengekspresikan emosinya. Namun ia akan memahami keterkaitan ekspresi wajah dengan emosi dan perasaan. Pada fase ini orang tua dapat membantu anak mengekspresikan emosi dengan bahasa verbal.Caranya orang tua menerjemahkan mimik dan ekspresi wajah dengan bahasa verbal. 3) Pada usia antara 2 sampai 3 tahun anak mulai mampu mengekspresikan emosinya dengan bahasa verbal. Anak mulai beradaptasi dengan kegagalan, anak mulai mengendalikan prilaku dan menguasai diri.

Ketiga, Usia antara 3 sampai 5 tahun.1) Pada fase ini anak mulai mempelajari kemampuan untuk mengambil inisiatif sendiri. Anak mulai belajar dan menjalin hubungan pertemanan yang baik dengan anak lain, bergurau dan melucu serta mulai mampu merasakan apa yang dirasakan oleh orang lain. 2) Pada fase ini untuk pertama kali anak mampu memahami bahwa satu peristiwa bisa menimbulkan reaksi emosional yang berbeda pada beberapa orang. Misalnya suatu pertandingan akan membuat pemenang merasa senang, sementara yang kalah akan sedih. Keempat, Usia antara 5 sampai 12 tahun.1) Pada usia 56 anak mulai mempelajari kaidah dan aturan yang berlaku. Anak mempelajari konsep keadilan dan rahasia.Anak mulai mampu menjaga rahasia. Ini adalah keterampilan yang menuntut kemampuan untuk menyembunyikan informasi- informasi secara. 2) Anak usia 7-8 tahun perkembangan emosi pada masa ini anak telah menginternalisasikan rasa malu dan bangga. Anak dapat menverbalsasikan konflik emosi yang dialaminya. Semakin bertambah usia anak, anak semakin menyadari perasaan diri dan orang lain. 3) Anak usia 9-10 tahun anak dapat mengatur ekspresi emosi dalam situasi sosial dan dapat berespon terhadap distress emosional yang terjadi pada orang lain. Selain itu dapat mengontrol emosi negatif seperti takut dan sedih. Anak belajar apa yang membuat dirinya sedih, marah atau takut sehingga belajar beradaptasi agar emosi tersebut dapat dikontrol. 4) Pada masa usia 11-12 tahun, pengertian anak tentang baikburuk, tentang norma-norma aturan serta 
nilai-nilai yang berlaku di lingkungannya menjadi bertambah dan juga lebih fleksibel, tidak sekaku saat di usia kanak-kanak awal. Mereka mulai memahami bahwa penilaian baik-buruk atau aturan-aturan dapat diubah tergantung dari keadaan atau situasi munculnya perilaku tersebut, nuansa emosi mereka juga makin beragam.

\section{E. Cara Mengembangkan Kecerdasan}

\section{Emosi Anak}

Menurut Harmoko (2005) dalam (Hidayati, 2014), kecerdasan emosi dapat diartikan kemampuan untuk mengenali, mengelola, dan mengekspresikan dengan tepat, termasuk untuk memotivasi diri sendiri, mengenali emosi orang lain, serta membina hubungan dengan orang lain. Jelas bila seorang individu mempunyai kecerdasan emosi tinggi, dapat hidup lebih bahagia dan sukses karena percaya diri serta mampu menguasai emosi atau mempunyai kesehatan mental yang baik. Faktor kematangan dan pengalaman belajar, juga kondisi lainnya mempengaruhi perkembangan emosi seseorang. Pada perkembangan emosi peserta didik, pengaruh faktor belajar lebih penting karena belajar merupakan faktor yang lebih dapat dikendalikan. Terdapat berbagai cara untuk mengendalikan lingkungan dan pengalaman belajar emosi, baik untuk memperkuat pola reaksi emosi yang diinginkan, atau menghilangkan pola reaksi yang tidak diinginkan.

Perkembangan emosi dapat dipelajari antara lain dengan cara atau metode berikut (Yanti Fauziah, 2005): pertama, Belajar emosi dengan cara coba dan ralat (trial and error learning), terutama melibatkan aspek reaksi. Anak mencoba-coba dalam mengekspresikan emosinya dalam bentuk perilaku yang dapat diterima. Kedua,Belajar dengan cara meniru (learning by imitation) dilakukan melalui pengamatan yang membangkitkan emosi tertentu pada orang lain. Anak belajar bereaksi dengan cara yang sama dengan ekspresi dari orang yang diamati dan ditiru perilakunya.Ketiga, Belajar dengan cara mempersamakan diri (learning by identification) dengan orang lain yang dikagumi atau mempunyai ikatan emosional dengan anak lebih kuat dibandingkan dengan motivasi untuk meniru sembarang orang. Keempat,Belajar melalui pengkondisian (conditioning) berarti belajar perkembangan emosi dengan cara asoiasi atau menghubungkan antara stimulus (rangsangan) dengan respon (reaksi). Pengkondisian lebih cepat terjadi pada anak kecil yang mempelajari perkembangan perilaku karena anak kurang mampu menalar, dan kurang pengalaman. Kelima, Belajar melalui pelatihan (training) dibawah bimbingan dan 
pengawasan guru atau orang tua. Dengan pelatihan, anak dirangsang untuk bereaksi terhadap hal-hal tertentu dan belajar mengendalikan lingkungan atau emosi dirinya.

Pada diri setiap individu, termasuk peserta didik usia sekolah dasar, ada emosi dominan yaitu satu atau beberapa emosi yang menimbulkan pengaruh terkuat terhadap perilaku seseorang dan mempengaruhi kepribadian anak, khususnya dalam penyesuaian pribadi dan sosial. Emosi dominan ini biasanya terbentuk dan bergantung pada lingkungan tempat anak hidup dan menjalin hubungan dengan orangorang yang berarti atau berpengaruh dalam kehidupannya, seperti kondisi kesehatan, suasana rumah, hubungan dengan anggota keluarga, hubungan dengan teman sebaya, perlindungan aspirasi orang tua, serta cara mendidik dan bimbingan orang tua.

Emosi dominan ini akan mewarnai temperamen anak dan bersifat menetap. Anak yang bertemperamen periang akan memandang ringan rintangan yang menghalangi langkahnya. Demikian juga, besarnya pengaruh emosi yang menyenangkan seperti kasih sayang dan kebahagiaan menyebabkan timbulnya perasaan aman yang akan membantu anak dalam menghadapi masalah dengan penuh ketenangan, kepercayaan dan keyakinan dapat mengatasinya, bereaksi terhadap rintangan denga ketegangan emosi yang minimal, dan dapat mempertahankan keseimbangan emosi.

Kesimbangan emosi dapat diperoleh melalui cara pengendalian lingkungan dengan tujuan agar emosi yang tidak/kurang menyenangkan dapat cepat diimbangi dengan emosi yang menyenangkan; mengembangkan toleransi terhadap emosi yaitu kemampuan untuk menghambat pengaruh emosi yang tidak menyenangkan (marah, kecemasan, dan frustrasi) dan belajar menerima kegembiraan dan kasih sayang. Terjadinya ketidakseimbangan antara emosi yang menyenangkan dan tidak menyenagkan akan membuat anak menjadi murung, cepat marah, dan watak negatif lainnya. Untuk itu diperlukan "katarsis emosi" yaitu keluarnya energi emosional yang dapat mengakngkat sebab terpendam, dan sekaligus membersihkan tubuh dan jiwa dari gangguan emosional. Kondisi emosi yang meninggi antara lain disebabkan oleh kondisi fisik (kesehatan buruk, gangguan kronis, perubahan dalam tubuh), kondisi psikologis (kecerdasan rendah, kecemasan, kegagalan mencapai aspirasi), dan kondisi lingkungan (ketegangan karena pertengkaran, sikap orang tua/guru yang otoriter, dan lain-lain). 


\section{KESIMPULAN}

Emosi merupakan hal dominan yang akan mewarnai anak dan bersifat menetap. Jika memandang ringan rintangan emosi pada anak niscaya akan yang menghalangi langkahnya kedepan baik pada tahap dasar maupun menengah bahkan dewasa. Demikian juga, besarnya pengaruh emosi seperti kasih sayang dan kebahagiaan menyebabkan timbulnya perasaan aman yang akan membantu anak dalam menghadapi masalah dengan penuh ketenangan, kepercayaan dan keyakinan dapat mengatasinya, bereaksi terhadap rintangan denga ketegangan emosi yang minimal, dan dapat mempertahankan keseimbangan emosi.

\section{REFERENSI}

Andi Widodo, A. P. (2018). Anak Dengan Hambatan Perilaku Emosi dan Sosial. Nizamia Learning Center.

Arafat, G. (2018). Membongkar Isi Pesan dan Media dengan Content Analysis Gusti Yasser Arafat UIN Antasari Banjarmasin. Jurnal Alhadrah, 17(33), 32-48.

Arikunto, S. (2016). Prosedur Penelitian: Suatu Pendekatan Praktik. Rineka Cipta.

Darmiah. (2020). Perkembangan dan FaktorFaktor yang Mempengaruhi Anak Usia MI. Pionir: Jurnal Pendidikan, $8(2)$.

Febiola, S., \& Hazizah, N. (2019). Peran Keluarga dalam Menangani Emosi
Negatif dan Pembentukan Karakter Anak Usia Dini. https://doi.org/10.31227/osf.io/94t6h

Hidayati, N. I. (2014). Pola Asuh Otoriter Orang Tua , Kecerdasan Emosi ,. Jurnal Psikologi Indonesia, 3(01).

Maria, I., \& Amalia, E. R. (2018). Perkembangan Aspek SosialEmosional dan Kegiatan Pembelajaran yang Sesuai untuk Anak Usia 4-6 Tahun. https://doi.org/10.31219/osf.io/p5gu8

Novi Ade Suryani. (2019). Kemampuan Sosial Emosional Anak Melalui Permainan Raba-Raba Pada PAUD Kelompok A. Potensia, 4(2), 141-150.

Rena, S. (2019). Mekanisme Respon Stres: Konseptualisasi Integrasi Islam Dan Barat. Psikis : Jurnal Psikologi Islami, 5(1), $\quad$ 48-61. https://doi.org/10.19109/psikis.v5i1.3 116

Sari, P. P., Sumardi, S., \& Mulyadi, S. (2020). Pola Asuh Orang Tua Terhadap Perkembangan Emosional Anak Usia Dini. Jurnal PAUD Agapedia, 4(1), 157-170.

Setiani, R. E. (2013). Memahami Pola Perkembangan Motorik Pada Anak Usia Dini. INSANIA: Jurnal Pemikiran Alternatif Kependidikan, 18(3), 455-470. https://doi.org/10.24090/insania.v18i3. 1472

Syamsu, Y. L. (2014). Psikologi Perkembangan Anak dan Remaja. Remaja Rosdakarya.

Yanti Fauziah, P. (2005). Pengembangan Kecerdasan Emosi Anak Sejak Dini. Diklus: Jurnal Pendidikan Luar Sekolah, 10(5), 73-86. 